\title{
Legenda Asal Usul Nama-nama Desa di Kecamatan Kemangkon Kabupaten Purbalingga
}

\author{
Dwi Noviyanti ${ }^{* 1}$ \\ 1,2Program Studi Sastra Jawa, Fakultas Bahasa dan Seni, Universitas Negeri Semarang
}

\section{Info Artikel}

\section{Article History:}

Diajukan January 9, 2019

Diterima June, 302019

Terbit June, 302019

\section{Kata kunci:}

cerita rakyat;

legenda;

asal-usul nama desa di

kecamatan kemangkon

\begin{abstract}
Abstrak
Legenda terjadinya desa-desa di Purbalingga tidak lepas dari berbagai cerita dan mitos yang dipercaya masyarakat pendukungnya. Cerita tersebut hidup dan menjadi salah satu pelengkap akan rasa kepemilikan desa oleh masyarakat. Penelitian ini bertujuan untuk (1) mendeskripsikan cerita legenda asal-usul nama desa di Kecamatan Kemangkon Kabupaten Purbalingga, dan (2) mendeskripsikan faktor yang melahirkan asalusul nama desa di Kecamatan Kemangkon Kabupaten Purbalingga. Penelitian ini merupakan penelitian deskripsi kualitatif dengan melalui pendekatan folklore, data diperoleh dari sumber data lisan hasil observasi, wawancara mendalam, perekaman dan pendokumentasian yang disajikan dalam bentuk deskripsi. Teknik pemaparan hasil data dilakukan dengan teknik informal. Hasil dari penelitian ini dapat ditemukan (1) deskripsi cerita legenda asal-usul nama desa di Kecamatan Kemangkon Kabupaten Purbalingga. (2) faktor yang mempengaruhi legenda asal-usul penamaan desa di Kecamatan Kemangkon Kabupaten Purbalingga. Faktor-faktor tersebut adalah (a) orang pertama sebagai pelopor, hadirnya seseorang yang datang ke suatu wilayah yang kemudian nama orang tersebut dijadikan sebagai nama desa di wilayah itu; (b) adanya perbedaan cerita, setiap desa memiliki cerita yang berbeda-beda antara desa satu dengan desa yang satunya walaupun dalam satu kecamatan; (c) adanya perlawanan, di Desa Panican ada 3 orang yang melawan harimau saat akan membuka permukiman baru yang kemudian peristiwa tersebut dijadikan nama desa panican (wani karo macan); dan (d) adanya peninggalan, peninggalan yang berada di Desa Kedungbenda yang berupa emas, dari banyaknya harta benda yang berada disana sehingga dijadikan nama desa.
\end{abstract}

\begin{abstract}
The legend through the villages in Purbalingga is inseparable from the stories and myths that are believed by the supporting community. This story lives on and becomes a complement to what the village feels to the community. This study aims to (1) describe the legendary story of the origin of the name of the village in Kemangkon Sub-District, Purbalingga Regency, and (2) describe the legend factor of the origin of the name of the village in Kemangkon Subdistrict, Purbalingga Regency. This research is a qualitative description research through aapproach folklore, data obtained from sources of oral data from observations, in-depth interviews, recording and documentation that are presented in the form of descriptions. The technique of exposure to data results is done by informal techniques. The results of this study can be found (1) description of the story of the legend of the origin of the name of the village in Kemangkon District, Purbalingga Regency. (2) factors that influence the legend of the origin of village naming in Kemangkon Subdistrict, Purbalingga Regency. These factors are (a) the first person as a pioneer, the presence of someone who comes to an area who then becomes the name of the person in the name of the village in that area; (b) there are differences in stories, each village has a different story from one village to the other even though it is in one sub-district; (c) there is resistance, in Panican Village there are 3 people who fight tigers when they are about to open new settlements which then become a panican village name (wani karo macan); and (d) there are relics, relics that are in the village of Kedungbenda in the form of gold, from the amount of property that is there so that it is used as the name of the village.
\end{abstract}

E-mail:dwi.nouviyanti@gmail.com

Alamat: Gedung B-8 Fakultas Bahasa dan Seni

Universitas Negeri Semarang

Kampus Sekaran, Gunungpati, Semarang 50229

DOI 10.15294/sutasoma.v7i1.33139 


\section{PENDAHULUAN}

Legenda merupakan salah satu bagian dari prosa cerita rakyat yang dianggap sebagai suatu cerita yang kejadiannya sungguh- sungguh pernah terjadi. Di dalam legenda ada empat kelompok, yaitu legenda keagamaan, legenda alam gaib, legenda perseorangan, dan legenda setempat (Brunvand dalam Danandjaja, 2002). Dalam penelitian ini membahas mengenai legenda setempat.

Penelitian ini meneliti cerita prosa rakyat yang ada di daerah Kecamatan Kemangkon Kabupaten Purbalingga yang berupa legenda asal-usul penamaan desa. Cerita rakyat legenda asal usul terjadinya suatu tempat dan nama tempat di Kecamatan Kemangkon ini ada kaitannya dengan sejarah. Sejarah yang terjadi pada jaman lampau yang ceritanya diseberluaskan secara turun temurun melalui lisan ke lisan atau biasa disebut dengan tutur tinular (Dundes dalam Hutomo, 1991), sehingga memungkinkan dari satu orang ke orang yang lain memiliki pemahaman yang berbeda atau memiliki cerita yang berbeda dengan sumber yang sama. Perbedaan versi bisa berkurang dan bertambah bergantung dengan orang yang bercerita dan orang yang diajak bercerita.

Menurut Ratna (2011), karena penyebarannya dalam bahasa lisan sehingga terjadi interaksi sosial, yaitu interaksi antara si penutur dengan yang dituturkan. Hal ini terlihat pada salah satu ciri-ciri dari cerita rakyat yaitu penyebaran dan pewarisannya dilakukan secara lisan. Dengan tradisi lisan inilah cerita rakyat dapat diketahui oleh masyarakat, karena merupakan bagian dari aset budaya yang harus dipertahankan ditengah perkembangan jaman yang semakin pesat. Dan juga Teknologi yang semakin canggih yang menawarkan berbagai hiburan dan informasi yang lebih beragam dan menarik mengakibatkan budaya lokal menjadi semakin tersisih.

Perkembangan cerita rakyat khususnya legenda di kehidupan masyarakat saat ini sudah sangat banyak, bahkan legenda yang terkenal sering kita jumpai di berbagai media sosial. Namun, legenda yang berada di sekitar kita seperti legenda asal-usul penamaan desa di Kecamatan Kemangkon malah kurang diketahui oleh masyarakat. Ketidaktahuan masyarakat dapat membuat cerita rakyat tersebut semakin menghilang dengan sendirinya. Kurangnya informasi baik lewat media cetak maupun media internet disebabkan karena minimnya alat untuk mengakses informasi tersebut. Hilangnya cerita rakyat juga disebabkan oleh perkembangan cerita rakyat yang penyebaran tidak merata.

Adanya cerita legenda asal-usul penamaan desa di wilayah Kecamatan Kemangkon ini, bertujuan untuk memberikan identitas suatu daerah kepada masyarakat luas yang akan menjadi ciri khas setiap daerah. Biasanya berkaitan dengan budaya pada masa lalu dan sebagian besar bersifat anonym, maksudnya tidak diketahui siapa pengarangnya sehingga untuk mengetahui sumber aslinya dan mengungkap isi ceritanya secara urut dan lengkap sangatlah sulit (Danandjaja, 2002).

Faktor lain yang mendorong cerita rakyat legenda asal-usul penamaan desa di Kecamatan Kemangkon dipilih sebagai objek penelitian karena untuk melestarikan budaya Jawa agar tidak musnah ditindas dengan per- kembangan ilmu pengetahuan dan teknologi. Perkembangan ilmu pengetahuan dan teknologi semakin lama akan semakin berkembang (Sudikan 2001). Hal yang ditakutkan adalah hilangnya ceritarakyat yang dipegang teguh oleh masyarakat. Selain itu, cerita rakyat legenda asal-usul penamaan desa di Kecamatan Kemangkon yang kurang berkembang. Maka dari itu, pada penelitian ini mendeskripsikan apa saja cerita yang ada di Kecamatan Kemangkon Kabupaten Purbalingga. Pentingnya legenda bagi masyarakat yaitu legenda mengandung nilai- nilai kearifan yang ditaati serta dipelihara sebagai sarana ikatan sosial, dan menjaga keberlangsungan legenda agar tetap ada di kalangan masyarakat.

Kecamatan Kemangkon merupakan salah satu dari 18 kecamatan yang ada di wilayah Kabupaten Purbalingga. Kecamatan Kemangkon ini terdiri dari 19 desa, yaitu Desa Bakulan, Bokol, Gambarsari, Jetis, Kalialang, Karangkemiri, Kedung Legok, Kedung Benda, Karangtengah, Kemangkon, Panican, Muntang, Sumilir, Toyareka, Pegandekan, Pelumutan, Majatengah, Majasem, Senon.

Sebelum terbentuknya wilayah Kecamatan Kemangkon, daerah tersebut merupakan hutan belantara dan masih sedikit warga yang tinggal di daerah tersebut. Tetapi sekarang sudah menjadi sebuah permukiman yang padat penduduknya.

Berdasarkan asumsi inilah peneliti melakukan penelitian cerita prosa rakyat mengenai legenda asal usul penamaan desa di Kecamatan Kemangkon. Penelitian ini menguraikan masalah tentang faktor apa saja yang mempengaruhi asal usul penamaan desa, serta bagaimana asal usul nama dari masing- masing desa yang ada di Kecamatan Kemangkon Kabupaten Purbalingga ini.

Tujuan dari penelitian ini adalah mendeskripsikan faktor yang melahirkan asal- usul nama-nama desa dan juga mendeskripsikan bagaimana asal-usul namanama desa itu terbentuk. Secara teoretis diharapkan dapat bermanfaat sebagai informasi dan juga tambahan pengetahuan tentang legenda asal usul suatu tempat yang ada di Indonesia khususnya di Jawa. Serta sebagai wacana pengenalan kepada pembaca tentang legenda penamaan desa ini.

Pemaparan hasil penelitian sebelumnya yang berkaitan dengan penelitian penulis yaitu yang dilakukan oleh Retno (2017), Nkoli dan Okoye (2016), Firdaus dkk (2013), Amin dkk (2013), Sukmawan (2017), Ruspandi dan Asep (2014), Dorji (2005), Djirong (2009), Sumaryono (2011), Hasyim dan Ali (2015), Setiawanti (2014).

\section{METODE}

Penelitian ini merupakan penelitian deskripsi kualitatif dengan melalui pendekatan folklore. Menurut Moleong (2010), metode kualitatif yang bersifat deskriptif dimaksudkan adalah bahwa data yang dikumpulkan berupa kata-kata baik tertulis maupun lisan dari orangorang dan juga perilaku yang dapat diamati. Hasilnya berupa pemaparan fakta-fakta secara tertulis mengenai objek yang ada di masyarakat dan pemaknaannya yang 
dilakukan secara lisan. Pendekatan ini memperhatikan kedua aspek yang ada dalam folklor, yaitu folk dan lorenya (Danandjaja dalam Asosiasi Tradisi Lisan, 2015:61). Sumber data dari penelitian ini adalah beberapa legenda asal-usul nama desa yang ada di wilayah Kecamatan Kemangkon Kabupaten Purbaalingga yang berupa cerita lisan yang diperoleh dari informan yang telah dipilih oleh penulis. Sumber data penelitian kualitatif adalah tampilan yang berupa kata- kata lisan atau tulisan yang dicermati oleh peneliti, dan benda-benda yang diamati sampai detailnya agar dapat diangkat makna yang tersirat dalam dokumen atau bendanya (Moleong dalam Arikunto 2010).

Teknik pengumpulan data dalam penelitian ini menggunakan teknik observasi, wawancara mendalam, perekaman dan pendokumentasian yang disajikan dalam bentuk deskripsi (Sudikan 2001). Pengumpulan data berupa observasi dilakukan dengan cara observasi terhadap lingkungan masyarakat yang mengetahui secara pasti cerita rakyat tersebut. Peneliti mendatangi setiap desa yang ada di wilayah Kecamatan Kemangkon Kabupaten Purbalingga untuk memperoleh data yang lengkap dan akurat. Teknik perekaman dilakukan untuk merekam informasi yang diceritakan oleh informan secara runtut yang nantinya akan ditranskrip menjadi bahan tertulis. Wawancara mendalam dilakukan untuk menggali data dan informasi tentang pengalaman individu, bagaimana proses, pemerolehan data yang dituturkan, dan unsur-unsur kebudayaan masyarakat setempat. Dokumentasi dalam penelitian ini berupa gambar yang berhubungan dengan objek penelitian serta mendokumentasikan proses pencarian data.

Teknik analisis data folklor meliputi dua hal, yaitu (1) teknik mandiri, artinya menganalisis data folklor tanpa memperhatikan unsur lain, (2) teknik interdisiplin, artinya cara menganalisis sebuah folklor dengan mengkaitkannya unsur kebudayaan lain (Endraswara 2009). Teknik analisis data folklor dalam penelitian ini dilakukan dengan mengumpulkan data dan informasi yang diperoleh dari kegiatan penelitian yang berupa pengamatan, perekaman, wawancara selanjutnya dipilah berdasarkan kategori tertentu. Kategori tersebut diantaranya faktor yang mempengaruhi legenda asal-usul penamaan desa di Kecamatan Kemangkon Kabupaten Purbalingga serta proses terbentuknya nama- nama desa di wilayah Kecamatan Kemangkon Kabupaten Purbalingga.

Teknik pemaparan hasil data dalam penelitian ini adalah hasil analisis data yang disajikan dalam bentuk deskripsi kualitatif, yaitu menghimpun data dari informan melalui wawancara yang kemudian dipaparkan dalam bentuk kata-kata bukan berupa angka-angka. Mengubah hasil cerita lisan ke dalam bentuk cerita tulis. Mengubah hasil cerita lisan ke dalam bentuk cerita tulis dari 16 desa yang telah peneliti teliti.

\section{HASIL DAN PEMBAHASAN}

Hasih dari penelitian ini pada pembahasan yang pertama adalah cerita asal usul nama-nama desa di Kecamatan Kemangkon. Ada 19 desa yang ada di Kecama- tan Kemangkon, dari keseluruhan itu tidak semua desa memiliki cerita yang lengkap mengenai awal mula penamaan desanya. Karena di era sekarang sulitnya mencari narasumber yang mengetahui cetita secara lengkap. Tak banyak juga orang mengetahui legenda penamaan desa. Dari banyaknya orang yang tinggal di desa tersebut hanya ada satu dua orang yang mengetahui legenda penamaan desa pada masing-masing desa. Penulis hanya meneliti 16 desa saja. Cerita legenda tersebut adalah dari desa Senon, Panican, Bokol, Kalialang, Kedungbenda, Kedung Legok, Kemangkon, Sumilir, Gambarsari, Karang Kemiri, Karangtengah, Bakulan, Majasem, Pelumutan, Majatengah, Toyareka. Deskripsi cerita legenda dari Desa Kedung Legok dan Desa kemangkon adalah sebagai berikut.

\section{Asal-usul Desa Kedung Legok}

Kedung Legok berasal dari 2 kata yaitu kedhung dan legok, kedhung yang berarti sebuah tempat seperti kolam yang terisi air, sedangkan legok adalah sebuah tempat yang permukaannya tidak rata atau biasa disebut berlubang. Berawal dari pada jaman dahulu ada seorang putri dari Kerajaan Majapahit yang sedang menaiki kudanya melintas ke daerah ini, lalu kuda tersebut terperosok kedalam sebuah lubang yang letaknya tidak jauh dari kedhung yang lumayan dalam itu. Akhirnya putri bersama dengan kudanya meninggal di tempat itu. Putri yang menaiki kuda tersebut bernama Putri Puspasari. Dari cerita tersebut maka oleh masyarakat sekitar dijadikan sebagai nama desa yaitu Desa Kedung Legok. Sejak kejadian tersebut, masyarakat meyakini kalau ada yang berkaitan dengan kuda, akan membahayakan diri mereka sendiri.

Di desa ini melarang masyarakatnya untuk memelihara jaran atau kuda dan juga dilarang mengadakan pertunjukan ebeg atau kuda lumping. Ada sebuah kisah, dahulu ada seseorang dari luar Desa Kedung Legok menaiki kuda dan akan melintas ke desa ini. Beliau tidak mengetahui adanya larangan tersebut. Pada saat akan memasuki wilayah ini sang kuda mbegod (menolak) dan meringkik ketakutan. Lalu sang pemilik pun tanpa pikir panjang turun dari kudanya dan dia membawa sang kuda untuk lewat melalui jalan lain. Pernah juga ada warga Desa Kedung Legok yang nekat untuk tetap memelihara kuda, karena menurutnya semua kejadian terdahulu itu hanya mitos belaka. Tetapi setelah selang beberapa minggu kuda itu berada di rumahnya, akhirnya orang tersebut meninggal dunia, padahal awalnya beliau tidak memiliki penyakit kronis apapun. Setelah dicari tahu penyebabnya ternyata orang tersebut meninggal karena kuda yang dia pelihara menimbulkan mala petaka baginya. Lalu ada juga sebuah cerita dari para remaja di Desa Kedung Legok yang katanya dia suka dengan kuda sampai suatu hari dia membeli hiasan bergambarkan kuda yang dipasang di dinding rumahnya, tidak lama kemudian kehidupan di dalam rumah itu jadi tidak harmonis lagi seperti sedia kala.

Menurut informasi dari masyarakat orang yang pertama kali datang ke daerah ini awalnya ada 2 orang, beliau kembar yang bernama Indrawati dan Indrakusu- 
ma. Indrawati merupakan seorang perempuan sedangkan Indrakusuma merupakan laki-laki. Kedua orang tersebut merupakan utusan dari salah satu kerajaan pada waktu itu. Beliau terdampar ke daerah ini dan akhirnya memutuskan untuk tinggal di Desa Kedung Legok ini. Menurut informasi dari narasumber, petilasan mereka letaknya terpisah. Petilasan Mbah Indrawati terdapat di salah satu pemakaman umum warga. Tempat ini dikeramatkan dan sering digunakan oleh masyarakat dari luar Desa Kedung Legok sebagai tempat panembahan. Lalu petilasan Mbah Indrakusuma berada di salah satu grumbul, yaitu Grumbul Cibuak. Letaknya di tengahtengah pekarangan dan tidak begitu terawat, karena setiap orang yang akan ke petilasan tersebut selalu dibuat kesasar oleh Mbah Indrakusuma. Menurut penjelasan masyarakat sekitar daerah petilasan, kebanyakan orang yang akan mengunjungi petilasan itu hanya untuk meminta sesuatu jadi menurut warga Mbah Indrakusuma tidak menyukai hal itu. Hanya orang-orang tertentu saja yang bisa sampai ke petilasan Mbah Indrakusuma tanpa kesasar.

Di Grumbul Cibuak ini banyak terdapat pohon bambu wulung, yang konon pohon bambu yang berada disitu bukan sembarang pohon, melainkan ada penunggunya. Ada yang namanya Mbah Ketuhu yang konon wujudnya beliau menyerupai macan (harimau). Lalu ada masyarakat yang tidak tahu tentang sejarah wilayah itu, beliau bermaksud mengambil beberapa pohon bambu yang ada di daerah itu, tidak disangka saat membelah salah satu bambu ternyata didalam bambu itu penuh dengan udang besar dan air. Beliau langsung mengembalikan pohon bambu tadi ketempat semula dan tidak akan lagi mengambil sembarangan apapun yang ada di pekarangan tempat dimakamkannya Mbah Indrakusuma itu.

\section{Asal-usul Desa Kemangkon}

Pada jaman dahulu kala ada sebuah cerita tentang adanya Mbah Mangku di daerah ini. Menurut cerita, Mbah Mangku itu tidak diketahui seperti apa tetapi masyarakat yakin bahwa beliau ada di daerah ini pada saat itu. Petilasan Mbah Mangku sampai sekarang pun masih ada. Dahulu petilasan tersebut sangat dihormati oleh warga Desa Kemangkon, tetapi sekarang sudah semakin luntur kepercayaan tersebut. Sosok Mbah Mang$\mathrm{ku}$ diyakini sebagai suatu sosok yang bijaksana, sakti, dan pandai. Mbah Mangku berada diwilayah ini bersama dengan para pepundennya. Legenda ini masih ada sangkut pautnya dengan Adipati Wirasaba. Keberadaan Mbah Mangku dahulu bersama Mbah Samanyana, beliau merupakan seorang dalang pada jaman tersebut. Kejadiannya pada jaman yoyorumpun dan cacinganil. Di Desa Kemangkon terdapat 3 pemakaman disetiap dusunnya. Desa ini juga sering mengadakan ruatan.

Di desa ini terdapat 3 dusun atau grumbul, pertama Grumbul Kedhung Tuk. Dinamakan Kedhung Tuk karena pada jaman dahulu jika terjadi hujan selalu tergenang air, airnya lama terserap ke tanah sehingga pada area makam di Grumbul Kedhung Tuk ini tidak lagi di jadikan tempat pemakaman dikarenakan seringnya terdapat genangan air. Jika tetap digunakan, takutnya keberadaan jenazah yang dimakamkan di tempat tersebut akan ambles. Kedhung itu artinya genangan air, tuk artinya ambles.

Kedua, Grumbul Kemojing. Dinamakan Kemojing karena di daerah tersebut terkenal dengan buah lobilobi. Sekarang buahnya sudah tidak ada hanya tersisa pohonnya saja, tetapi sudah jarang keberadaannya dikarenakan sudah banyak dijadikan area permukiman. Kemojing itu sendiri artinya buah. Ketiga, Grumbul Karang Moncol. Karang yang artinya kebun, sedangkan moncol artinya paling terlihat dari lainnya. Grumbul ini merupakan bagian awal dari Desa Kemangkon jadi setiap orang yang lewat selalu melewati grumbul ini terlebih dahulu.

Desa Kemangkon diapit oleh dua sungai, yaitu Sungai Serayu dan Sungai Kelawing. Desa ini juga memberikan kemakmuran bagi warganya dengan tanah yang subur yang bisa ditanami berbagai tanaman yang menghasilkan. Petilasan Mbah Mangku selalu didatangi oleh para peziarah setiap hari rabu pon. Bentuk nyata keberadaan Mbah Mangku, setiap akan mencalonkan diri menjadi kepala desa harus izin ke petilasan. Nama Desa Kemangkon dahulu ada orang yang datang ke daerah ini merasa betah. Setiap orang pasti suka yang namanya dipangku maka dari itu kata kemangkon berasal dari kata pangku yang kemudian untuk mempermudah pengucapan sehingga menjadi kemangkon. Batas Desa Kemangkon pada sebelah timur berbatasan dengan Wirasaba, sebelah barat berbatasan dengan Desa Kedung Legok, sebelah utara berbatasan dengan Panican, dan sebelah selatan berbatasan dengan Kabupaten Banjarnegara. Larangan yang ada di desa ini yaitu tidak boleh menggunakan barang yang sama. Contohnya ada 2 orang dilokasi yang sama menggunakan baju yang sama maka salah satunya harus mengganti bajunya, karena hal itu akan menimbulkan emosi dari kedua belah pihak.

\section{Faktor yang Mepengaruhi Cerita}

Faktor yang mempengaruhi legenda asal- usul nama desa dan deskripsi cerita legenda asal-usul nama desa di Kecamatan Kemangkon Kabupaten Purbalingga. Adanya sebuah nama dalam sebuah wilayah pasti terdapat beberapa faktor yang mempengaruhinya. Maka dari itu dibawah ini akan disebutkan beberapa faktor yang mempengaruhi adanya sebuah nama disuatu daerah tertentu. Faktor-faktor tersebut antara lain a) Orang pertama sebagai pelopor, b) Adanya perbedaan cerita, c) Adanya suatu perlawanan, d) Adanya peninggalan di daerah itu.

\section{Orang Pertama Sebagai Pelopor}

Daftar legenda nama-nama desa yang masuk dalam kategori faktor pertama yaitu (1) Desa Kemangkon, (2) Desa Bakulan, dan (3) Desa Majasem, (4) Desa Senon. Hasil wawancara yang menunjukan terbentuknya karena ada orang pertama yang datang kewilayah ini yaitu sebagai berikut. Percakapan antara penulis dan narasumber dari Desa Bakulan. Penulis melakukan wa- 
wancara dengan Bapak Suwarno dan Bapak Kurniawan. Hasil wawancara dengan beliau yaitu sebagai berikut.

\section{Wawancara 1}

Penulis : Kados pundi legendha asal-usul desa Bakulan menika?

(Bagaimana legenda asal-usul Desa Bakulan?)

Suwarno : Ana putri kerajaan jenenge Dewi Sundari sing nyamar dadi bakul sayur nang wilayah kene wektu kuwe. Warga sekitar langka sing ngerti jeneng asline bakul sayur kuwe, supaya gampang dadine warga nyeluk panjenengane kuwe Mbah Bakul. Mbah Bakul dodole ider maring desa-desa sekitar. Panjenengane manggon nang lahan kosong, lahan kuwe siki dadi desa. Desane diarani Desa Bakulan, mergane sing mbukak lahan pertama kuwe Mbah Bakul.

(Ada seorang putri dari sebuah kerajaan yang bernama Dewi sundari, beliau menyamar sebagai penjual sayuran keliling pada waktu itu. Para warga tidak ada yang mengetahui nama penjual sayur tersebut, sehingga wara warga hanya memanggilnya dengan panggilan Mbah Bakul. Beliau berjualan keliling desadesa sekitar. Beliau tinggal disuatu daerah yang masih kosong, yang kemudian menjadi sebuah desa. Desa tersebut diberi nama Desa Bakulan karena Mbah bakul yang pertama kali membuka lahan tersebut.

\section{Wawancara 2}

Penulis : Miturut Bapak kados pundi legendha asal-usul Desa Bakulan Menika?

(Menurut pendapat bapak seperti apa legenda asal-usul Desa Bakulan?)

Kurniawan: Inyong ora ngerti pasthine mbak, mung mbiyen krungu crita kang wong tuwa jerene pas jaman kuwe ana embah-embah dodolan sayur. Mbah kuwe diceluke Mbah Bakul nang para warga. Mbah Bakul manggon nang lahan kosong, suwe-suwe lahan kuwe dijenengi Bakulan.

(Saya tidak mengetahui cerita pastinya seperti apa, dahulu pernah diceritakan oleh orang tua katanya ada embah yang berjualan sayur. Beliau dipanggil Mbah Bakul oleh masyarakat. Mbah Bakul tinggal disebuah lahan kosong yang kemudian lahan tersebut menjadi sebuah desa yang diberi nama Desa Bakulan.)

Orang pertama yang datang ke Desa Bakulan adalah seorang putri dari sebuah kerajaan. Beliau menyamar menjadi seorang nenek-nenek yang berjualan sayuran keliling dari desa ke desa. Putri kerajaan tersebut bernama Dewi Sundari, tetapi karena masyarakat tidak mengetahui nama aslinya jadi dipanggil Mbah Bakul. Mbah tersebut tinggal di sebuah lahan kosong, lahan tersebut lama kelamaan menjadi sebuah desa. Desa tersebut diberi nama Desa Bakulan.

\section{Adanya Perbedaan Cerita}

Pada faktor yang kedua yaitu adanya ciri- ciri khusus yang tidak dimiliki oleh desa lainnya. Berikut 10 desa yang dikategorikan dalam faktor tersebut adalah Desa Kedung Legok, Desa Karangkemiri, Desa Karangtengah, Desa Pelumutan, Desa Toyareka, Desa Gambarsari, Desa Kalialang, Desa Sumilir, Desa Majatengah, Desa Bokol.

Faktor yang kedua ini mendominasi faktor-faktor yang lainnya. Berikut ini kutipan dari cerita legenda yang masuk dalam faktor kedua. Legenda asal-usul Desa Kedung Legok. Dalam mencari informasi mengenai legenda asal-usul desa ini penulis melakukan wawancara dengan narasumber. Narasumber yang penulis wawancarai yaitu Bapak Tugiyo dan Bapak Ruswandi. Berikut hasil wawancara dengan kedua narasumber.

Penulis : Kados pundi legendha asal-usul Desa Kedung Legok?

(Bagaimana legenda asal-usul Desa Kedung Legok?)

Narasumber : Sak ngertiku, Desa Kedung Legok kuwi merga gabungan saka 2 kata yaiku kata kedhung lan kata legok. Kedhung kuwi artine panggonan kang jero sing biasane isi banyu, lan legok kuwi artine bagian dalan sing dhekok. Critane kuwi mbiyen ana putri kerajaan numpak jaran lah ijig-ijig jarane mblusuk nang legokan lan kejronjong tiba maring kedhung. Putrine juga melu tiba, akire jaran lan putri kerajaan kuwi ninggal nang kono. Putri kerajaan kuwi arane putri Puspasari. Kanggo ngemut-emut kedadean kuwi akire didadekake jeneng desa Kedung Legok.

(Sepengetahuan saya, Desa Kedung Legok itu gabungan dari 2 kata yaitu kedhung dan legok. Kedhung artinya bagian tempat yang dalam yang biasanya berisi air, daan legok itu artinya bagian jalan yang berlubang. Ceritanya dahulu itu ada salah satu purti kerajaan yang sedang menaiki kuda dan tiba-tiba kuda tersebut terperosok ke dalam lubang dan masuk ke sebuah kolam yang dalam. Sang putri kerajaan tersebut pun ikut terjatuh ke bersama kudanya, sampai akhirnya meninggal di tempat itu. Putri tersebut bernama putri Puspasari. Untuk mengingat kejadian tersebut akhirnya dijadikan nama desa, yaitu Desa Kedung Legok

Dari 2 narasumber yang penulis wawancarai memberikan informasi cerita yang hampir sama sehingga penulis menggabungkan hasil wawancara menjadi satu.

Legenda asal-usul Desa Kalialang. Penulis melakukan wawancara dengan Bapak Sarmadi dan Bapak Asih. Berikut ini kutipan cerita legendanya.

Wawancara 1

Penulis: Kados pundi cariyosipun legendha asal-usul Desa Kalialang menika pak? 
(Bagaimana cerita legenda asal-usul Desa Kalialang itu pak?)

Asih : Miturut crita mbiyen ana kali jenenge Kali Pong sing ngalir saka Desa Karangtengah nglewati wilayah iki. Nanging sawijining dina ijig-ijig kali kuwe ilang. Ilange merga ana banjir gedhe, lan banjire ora surut malah dadi rawa. Mula saka ilange kali kuwi daerahe dadi dijenengi Desa Kalialang. (Menurut cerita dahulu ada sungai yang namanya Sungai Pong yang mengalir dari Desa Karangtengah melewati wilayah tersebut. Tetapi suatu hari tiba-tiba sungai itu hilang. Hilangnya sungai tersebut karena adanya banjir yang besar yang menenggelamkan kali tersebut, dan banjir tersebut pun tidak surut hingga akhirnya menjadi sebuah rawa. Dari hilangnya sungai tersebut, maka daerah itu diberi nama Desa Kalialang.)

Wawancara 2

Penulis: Kados pundi cariyosipun legendha asal usul Desa Kalialang menika?

(Bagaimana cerita legenda asal-usul Desa Kalialang itu?)

Sarmadi : Padha jaman kuwi, daerah iki ana kali sing jenenge kali Ponggawa sing nang pinggir-pinggire akeh wit alang-alange. Sawijining dina ana banjir gedhe nganti ngelelepake kali lan wit alang-alang sing ana nang kana. Saka ilange kali lan alang-alang kuwi dadine daerah iku dijenengi Kalialang, banjur dienggo kanggo jeneng desa.

(Pada jaman Tersebut, di daerah ini ada sebuah sungai yang bernama sungai Ponggawa dan disekitar sungai tersebut banyak ditumbuhi ilalang. Suatu hari ada banjir besar datang hingga menenggelamkan sungai dan pohon ilalang yang ada disekitarnya. Dari hilangnya kali dan ilalang tersebut sehingga daerah itu diberi nama Kalialang, lalu dipakai sebagai nama desa.)

Hasil wawancara antara keduanya sedikit ada perbedaan. Menurut Bapak Asih terjadinya Desa kalialang karena hilangnya kali yang berubah menjadi rawa-rawa. Sedangkan menurut Bapak Sarmadi terjadinya Desa kalialang karena hilangnya kali dan pohon ilalang akibat banjir besar.

Legenda asal-usul Desa Sumilir. Penulis melakukan wawancara dengan Bapak Daryanto. Berikur kutipan cerita legenda tersebut.

Penulis : Kados pundi cariyosipun legendha asal-usul Desa Sumilir menika?

(Bagaimana cerita legenda asal-usul Desa Sumilir?)

Daryanto : Wektu jaman kuwe ana wong lanang karo bojone sing liwat daerah iki. Banjur pas nang dalan krasa kesel, lan nggolet panggonan aub dienggo ngaso. Ana wit gedhe nang pinggir kali, wong loro kuwi banjur ngaso nang ngisor wit karo ndeleng miline kali. Silirsilir angin sing liwat gawe wong loro kuwi ngantuk. Sawise cukup anggone ngaso mau, wong loro kuwe nglanjutake lakune. Urung adoh karo panggonan sing mau dienggo ngaso, banjur wong loro kuwi ngomong lan njenengi daerah mau Sumilir sing asale saka kata silir-silir angin.

(Waktu jaman itu ada sepasang suami istri melewati daerah ini. Sewaktu diperjalanan mereka kelelahan, dan bermaksud mencari tempat berteduh untuk beristirahat. Ada pohon besar yang berada di pinggir sungai, lalu mereka beristirahat dibawah pohon tersebut sambil melihat lajunya air di sungai itu. Sepoi- sepoi angin yang lewat membuat mereka mengantuk. Setelah dirasa cukup untuk beristirahat, mereka lalu melanjutkan perjalanannya. Belum begitu jaug dari tempatnya berteduh, mereka berucap dan memberi nama daerah tersebut dengan nama Sumilir yang berasal dari kata silir-silir.)

\section{Adanya Sesuatu Perlawanan}

Berikutnya yang termasuk dalam faktor ketiga yang melahirkan adanya penamaan desa yaitu faktor adanya sesuatu hal yang dilakukan yang menjadikannya nama sebuah desa. Desa yang termasuk dalam faktor ini yaitu Desa Panican. Dibawah ini kutipan cerita legenda asal usul desanya berdasarkan wawancara dengan narasumber. Penulis melakukan wawancara dengan Bapak Anto.

Penulis: Kados pundi cariyosipun legendha asal-usul nami Desa Panican menika?

(Bagaimana cerita legenda asal-usul nama Desa Panican itu?)

Anto: Ana 3 prajurit sing arep mbukak lahan didadekake mukim warga. Para prajurit kuwi arane Wisananga, wisanala, lan Wisayudha. Sawise guthul panggonan sing dituju, wong 3 kuwi ketemu karo macan penghuni utan kuwi. Macane nyerang wong 3 kuwi, banjur dilawan karo tobak sing wis digawa nang wongwong kuwi. Akire wong 3 kuwi menang nglawan macan lan nglanjutake niat awale sing dituju yaiku mbukak lahan. Saka kedadean kuwi daerah kono dijenengi Wanican yaiku kasil singkatan saka wani karo macan. Merga wanican kuwi angel anggone ngucapna, dadine diganti Panican kanti tekan siki.

(Ada 3 prajurit yang akan membuka lahan untuk dijadikan permukiman warga. Para prajurit tersebut bernama Wisananga, Wisanala, lan Wisayudha. Sesampainya ke lahan yang dituju, ketiga orang tersebut bertemu macan (harimau) penunggu hutan tersebut. Macan kuwi nyerang wong 3 mau, lalu dilawan menggunakan tombak yang sudah mereka bawa. Pada akhirnya mereka memenangkan perlawanan tersebut dan melanjutkan pada niat awalnya tadi. Dari peristiwa tersebut daerah itu diberi nama Wanican yang berasal dari singkatan 
wani karo macan. Tetapi karena Wanican susah untuk dilafalkan sehingga diganti menjadi Panican sampai dengan sekarang.) Desa Panican terbentuk dari adanya 3 prajurit yang telah berani melawan harimau hutan yang dikenal sangat ganas tersebut. Karena ketiga prajurit tersebut juga sehingga ada desa ini.

\section{Adanya Sebuah Peninggalan di Daerah Itu}

Faktor yang terakhir yaitu adanya sebuah peninggalan yang menjadikannya sebuah nama desa. Legenda nama desa yang masuk dalam faktor ini yaitu Desa Kedungbenda. Penulis melakukan wawancara denga Bapak Gito. Berikut ini hasil ceritanya.

\section{Penulis : Kados pundi cariyosipun legendha asal-usul desa Kedungbenda menika?}

(Bagaimana cerita legenda asal-usul Desa Kedungbenda itu?)

Gito : Daerah iki panggonane antarane Kali Serayu lan Kali Klawing. Nang kene terkenal daerah sing nduweni harta karun. Hartane kuwi awujud emas, ana emas awujudbatangan, anasingwiswujudkalung lan liya-liyane. Emas-emas kuwe bakalan katon nek mangsan terang, amarga nek mangsan kuwi kan banyu kali padha sat. wong-wong sing pada nemu emas kuwi ora wani ngedol maring wong liya, kudu disimpen. Amarga nek didol mengko wonge bakalan ninggal, jerene kaya kuwe. Saka kedadean kuwe dadine desa kie dijenengi Desa Kedungbenda merga akeh benda awujud emas mau. Desa Kedungbenda kuwe asal saka tembung kedhung lan benda. Kedhung sing artine panggonan jero sing biasane isi banyu, lan benda yaiku harta.

(Daerah ini merupakan tempat yang terletak diantara Sungai Serayu dan Sungai Klawing. Disini terkenalnya dengan daerah yang memiliki harta karun. Hartanya itu berupa emas, ada yang berupa emas batangan, ada yang berwujud kalung dan lain sebagainya. Emas-emas tersebut akan terlihat saat musim terang, karena air akan surut. Orangorang yang menemukan emas tersebut tidak berani menjualnya, mereka memilih untuk menyimpannya. Karena kalau dijual maka sang pemilik emas tersebut akan meninggal, begitu kata orang-orang. Dari peristiwa ini maka desa ini diberi nama Desa Kedungbenda karena banyak ditemukan harta yang berupa emas tersebut. Desa Kedungbenda itu berasal dari kata kedhung dan benda. Kedhung artinya tempat yang dalam yang berisi air, benda yaitu harta.

\section{SIMPULAN}

Berdasarkan hasil penelitian dan pembahasan yang telah diuraikan, maka dapat ditarik simpulan 1) Cerita asal-usul desa yang terdapat di Kecamatan Kemangkon Kabupaten Purbalingga memiliki cerita masing-masing antara desa satu dengan desa yang lainnya. Cerita tersebut berbeda-beda tetapi saling terkait satu sama lain. Peneliti mengambil 16 desa dari 19 desa yang ada di Kecamatan Kemangkon Kabupaten Purbalingga. 2) faktor yang mepengaruhi adanya asal-usul penamaan desa di Kecamatan Kemangkon Kabupaten Purbalingga yaitu ada 4 . Faktor-faktor tersebut yaitu a) adanya orang pertama yang datang kewilayah tersebut yang menjadikannya sebagai pelopor, b) daerah tersebut memiliki ciri-ciri khusus yang tidak dimiliki oleh daerah lain, c) melakukan sesuatu perlawanan yang akhirnya menjadikannya sebagai nama di suatu daerah d) ada sesuatu peninggalan di daerah itu. Dari 16 legenda asal-usul penamaan desa yang termasuk kedalam faktor pertama yaitu Desa Kemangkon, Desa Bokol, Desa Majasem, dan Desa Senon. Yang termasuk dalam faktor kedua yaitu Desa Kedung Legok, Desa Karangkemiri, Desa Karangtengah, Desa Palumutan, Desa Toyareka, Desa Gambarsari, Desa Kalialang, Desa Sumilir, Desa Majatengah, dan Desa Bokol. Cerita asal usul desa yang masuk dalam faktor yang ketiga yaitu Desa Panican. Dan yang masuk dalam faktor yang terakhir yaitu cerita Desa Kedungbenda.

\section{DAFTAR PUSTAKA}

Amin, dkk. 2013. Cerita Rakyat Penamaan Desa di Kerinci: Kategori dan Fungsi Sosial Teks. Jurnal Bhasa, Sastra dan Pembelajaran Volume1 Nomor 1. Padang: Universitas Negeri Padang.

Arikunto, Suharsini. 2010. Prosedur Penelitian Suatu Pendekatan Praktek. Jakarta: Rineka Cipta.

Arneti. Asal-Usul Penamaan Nama-nama Jorong di Kanagarian Batukambiang Kecamatan Ampek Nagari Kabupaten Agam. Skripsi. Universitas Negeri Padang, Sumatra Barat.

Asosiasi Tradisi Lisan. 2015. Metode Kajian Tradisi Lisan. Jakarta: yayasan putera obor.

Danandjaja, James. 2002. Foklore Indonesia Ilmu Gosip, Dongeng, dan lain-lain. Jakarta: Pustaka Utama. Departemen pendidikan dan k e budayaan. 1995. Sastra Lisan Tetun. Jakarta.

Dewi, Fista Nuhlia Kumala. 2015. Inventarisasi Cerita Rakyat di Kabupaten Sragen. Skripsi. FBS: Universitas Negeri Semarang.

Djirong, salmah. 2011. Cerita Rakyat Makassar Tuappaka Sisarikbattang: Suatu Tinjauan Aspek Nilai. Sawerigading, Vol. 15, No. 2 Agustus 2009: 227-234. Makassar: Balai Bahasa Ujung Pandang

Dorji, Tshering Cigay. 2005. Preserving Our Folktales, Myths, and Legends In The Digital Era. Journal of Bhutan Studies. Buthan:-

Endraswara, Suwardi. 2009. Metode Penelitian Foklor. Yogyakarta: Media Pressindo.

Firdaus, dkk. 2013. Cerita Rakyat Masyarakat Rambah Kabupaten Rokan Hulu Provinsi Riau. Jurnal Bahasa, Sastra dan Pembelajaran Volume 1 Nomor 2. Padang: Universitas Negeri Padang.

Hasyim, Noor dan Ali Muqoddas. 2015. Inventarisasi Cerita Rakyat Dari Kabupaten Demak Melalui Aplikasi Buku Digital (E\Book) Interaktif. Andharupa, Jurnal Desain Komunikasi Visual \& Multimedia. Vol.01 No.02. Semarang: Program Studi Desain Komunikasi Visual, Fakultas Ilmu Komputer.

Hutomo, Suripan Sadi. 1991. Pengantar Studi Sastra 
Lisan. Jawa Timur: Himpunan Sarjana Kesusastraan Indonesia.

Istiana. 2012. Bentuk dan Makna Nama-nama Kampung di Kecamatan Kotagede. Skripsi. FBS: Universitas Negeri Yogyakarta.

Kinasih, Tri. 2010. Nama-nama Dusun di Kecamatan Kendal KabupatenKendal (Kajian Folklor). Skripsi. FBS:Universitas Negeri Semarang.

Krismiyati, Mariana. 2010. Mitos Asal Usul Desa Ngablak Kecamatan Kluwak Kabupaten Pati. Skripsi. FBS. Universitas Negeri Semarang.

Kurniawan, Herlan. 2008. Cerita Rakyat Kahyangan di Kelurahan dlipih Kecamatan Tirtomoyo Kabupaten Wonogiri dan Fungsi nya bagi Masyarakat: Tinjauan Resepsi. Skripsi. FKIP: Universitas Muhammadiyah Surakarta.

Moleong, Lexy J. 2010. Metodologi Penelitian Kualitatif. Bandung: PT Remaja Rosdakarya.

Mustiyanti, Putri. 2009. Mitos Asal Usul Kaliwungu di Kabupaten Kendal. Skripsi. FBS. Universitas Negeri Semarang.

Nkoli, Mercy Nnyigide \& Adaobi Ngozi Okoye. 2016. Igbo Folktales and Igbo Youths Development: The Need For Revitalization of Igbo Folktales. Mgbakoigba, Journal of African Studies. Vol 6 No 1. Nigeria:-

Rahayu, Tri. 2006. Cerita Sendang Jamur Dipo Sebagai Aset Budaya. Skripsi. FBS. Universitas Negeri Semarang.

Rampan, Korrie Layun. 2014. Teknik Menulis Cerita
Rakyat. Bandung: Yrama Widya.

Ratna, Nyoman Kutha. 2011. Antropologi Sastra. Yogyakarta: Pustaka Pelajar.

Retno M, Laura Andri. 2017. Cerita Rakyat Ondorante Pembentuk Pola Perilaku dan Identitas Masyarakat. NUSA, vol 12 No 3. FIB: Universitas Diponegoro.

Rukmini, Dewi. Cerita Rakyat Kabupaten Sragen (Suatu Kajian Struktural dan Nilai Edukasi). Tesis. Pascasarjana: Universitas Sebelas Maret.

Ruspandi, Jeko dan Asep Mulyadi. 2014. Fenomena Geografis di Balik Makna Toponimi di Kota Cirebon. Jurnal Gea Volume 14 Nomor 23. Jakarta: Departemen Pendidikan Geografi, Universitas Pendidikan Indonesia.

Setiawanti, Yuliana. 2014. Rekonstruksi Cerita Rakyat Djaka Mruyung Di Kabupaten Banyumas. SUTASOMA 3 (1). Semarang: Jurusan Bahasa Jawa, Fakultas Bahasa dan Seni.

Sudikan, Setya Yuwana. 2001. Metode Penelitian Sastra Lisan. Jakarta: Citra Wacana.

Sukmawan, Sony. 2017. Environmental Messages as Found in Indonesia Folklore and Its Relation to Foreign Language Classroom. Arab World English Journal (AWEJ) Vol.8. No. 1 March 2017. Arab:-

Sumaryono. 2011. The Story of Panji Between History Myths and Legend. Jurnal volume 26, nomer 1. Yogyakarta: Jurusan Seni Tari, Fakultas Seni Pertunjukan. 